\title{
Sosyolojide Eleştirel Düşünme: Sosyoloji Öğrencilerinin Eleştirel Sosyolojik Düşünme Beceri Düzeyleri Üzerine Bir Değerlendirme
}

\author{
Mahmut GÜRSOY ${ }^{1}$
}

$\ddot{O} z$

Üniversitelerdeki sosyoloji bölümlerinin en önemli ve müşterek öğretim hedeflerinden biri öğrencilerin sosyal olgulara ilişkin eleştirel düşünme becerilerini geliştirmektir. Buna rağmen, eğitimle ilgili böylesi bir kazanımı değerlendirmek üzere tasarlanmış ampirik araştırma yok denecek kadar azdır. Bu çalş̧ma, sosyolojideki lisans öğrencilerinin toplumsal konularla ilgili eleştirel sosyolojik düşünme becerilerini ölçmeyi ve bölümün olağan müfredatı içerisinde eğitim aşamaları ilerledikçe bu becerilerin bir gelişim gösterip göstermediğini ya da ne düzeyde geliştiğini test etmeyi amaçlamışıı. Betimsel araştırma modeline göre gerçekleştirilen çalışmanın katılımcıları 20182019 eğitim-öğretim yll bahar yarıylında Adıyaman Üniversitesi Fen-Edebiyat Fakültesi Sosyoloji Bölümü’nde öğrenim gören öğrencilerdir. Öğrencilerden, eleştirel sosyolojik düşünme beceri düzeylerini tespit etmek için tasarlanmış bir konuda kompozisyon yazmaları istenmiş ve çalışmanın verileri bu kompozisyonlardan elde edilmiştir. Verilerin analizinde ise "Eleştirel Sosyolojik Düşünme Ölçeği" kullanılmıştır. Eleştirel sosyolojik düşünme becerilerini 11 boyutta değerlendiren çalışmanın bulguları, öğrencilerin beceri düzeylerinin bölümün olağan müfredatı içerisinde eğitim aşamaları ilerledikçe hem boyutların her birinde hem de genel açıdan sürekli bir artış gösterdiğini ortaya koymuştur. Ancak nihai olarak öğrencilerin eleştirel sosyolojik düşünme becerilerinin istenen düzeye ulaşıığını söylemek güçtür. Uygulanan öğretim programının öğrencilere disipline özgü eleştirel düşünme becerisi kazandırmada yeterince etkili olmadığı anlaşılmaktadır.

Anabtar Kelimeler: Eleştirel sosyolojik düşünme, Sosyolojik tahayyül

\section{Critical Thinking in Sociology: An Evaluation on Sociology Students' Critical Sociological Thinking Skill Levels}

\section{Abstract}

One of the most important and common teaching goals of sociology departments in universities is to develop students' critical thinking skills about social facts. Nevertheless, empirical research designed to assess such an educational outcome is scarcely absent. This study aimed to measure the critical sociological thinking skills of undergraduate students in sociology related to social issues and to test whether these skills have improved as the education stages progressed within the department's regular curriculum. The participants of the study was chosen according to the descriptive research model; students studying in the Department of Sociology at the Faculty of Arts and Sciences in Adiyaman University in the spring semester of the 2018/2019 academic year. Students were asked to write a composition on a subject designed to determine their critical sociological thinking skill levels and the data of the study were obtained from these compositions. In the analysis of the data, "Critical Sociological Thinking Scale" was used. The findings of the study evaluating the critical sociological thinking skills in 11 dimensions revealed that the skill levels of the students increased both in each dimension and in general as the education stages progressed within the regular curriculum of the department. However, it is difficult to say that students' critical sociological thinking skills have finally reached the desired level. It is understood that the applied curriculum is not effective enough to provide students with critical thinking skills for specific to discipline.

Key Words: Critical sociological thinking, Sociological imagination

\section{Atıf İçin / Please Cite As:}

Gürsoy, M. (2021). Sosyolojide eleştirel düşünme: sosyoloji öğrencilerinin eleştirel sosyolojik düşünme beceri düzeyleri üzerine bir değerlendirme. Manas Sosyal Arasttrmalar Dergisi, 10(2), 1353-1368.

Geliş Tarihi / Received Date: 05.06.2020

Kabul Tarihi / Accepted Date: 14.01.2021

\footnotetext{
${ }^{1}$ Dr. - Adiyaman Üniversitesi, Rektörlük, magursoy@adiyaman.edu.tr 


\section{Giriş}

Üniversitelerdeki sosyoloji bölümlerinin en önemli ve müşterek öğretim hedeflerinden biri ögrencilerin sosyal olgulara ilişkin eleştirel düşünme becerilerini geliştirmektir. Sosyolojideki öğretim elemanları ekseriyetle, öğrencileri sosyal dünyaya ilişkin düşünmelerinde daha rasyonel, daha makul, daha eleştirel, dolayısıyla daha bilimsel olmaya teşvik etme yönündeki öğretim hedefine bağlı kalmaktadırlar. Öyle ki öğretim hedeflerini sıralamaları istendiğinde, öğrencilerin eleştirel düşünme becerilerini geliştirmeyi en üst basamağa koymaktadırlar.

Eleştirel düşünme kavramı, inançlarımızı ve kanaatlerimizi duygulara, ideolojiye, moda fikirlere, geleneksel inanışlara ve bu tür rasyonel olmayan temellere dayandırdığımız düşünme tarzından uzaklaşıp, bunun yerine ampirik kanıtlarla desteklenmiş, mantıksal olarak sağlam temellere dayalı bir düşünme alışkanlığ1 edinmeyi vurgulamaktadır (Logan, 1976, s. 30). Sosyoloji disiplinine özgü eleştirel düşünme Grauerholz ve Bouma-Holtrop (2003, s. 485) tarafindan literatüre kazandırıldığ şekliyle "eleştirel sosyolojik düşünme"- ise bir sorunu veyahut argümanı, onu etkileyen sosyal güçlerin ve içinde şekillendiği toplumsal bağlamın bilinciyle ve duyarlığıyla makul ve de sağduyulu bir şekilde değerlendirme becerisini ifade etmektedir.

Sosyoloji alanında eleştirel düşünmeyi önemli kılan nedir? Eleştirel sosyolojik düşünmenin temel işlevi kişiyi daha duyarlı hale getirmesidir. Böylece sağduyu keskinleşir ve mevcut ancak görünmez olan insanlık durumlarını keşfetmek kolaylaşır (Bauman, 2018, s. 27). Eleştirel sosyolojik perspektif, insan yaşamına dair geniş, açık ve kendini sınırlanmış hissetmeyen bir düşünsel bakış sunar. Bu nedenle sosyolog aynı olgulara diğer insanlardan başka türlü bakar. Zira onun referans çerçevesi farklıdır ve o, sürekli olarak sosyal sistemlerin iç yüzünü ortaya çıkarma mantığına tabidir. Nitekim Berger'in (2018, s. 36-45) dediği gibi, hiçbir şey göründüğü gibi değildir. Sosyal gerçekliğin pek çok anlam katmanı vardır. Her bir yeni katmanın keşfi ise bütün algiyı değiştirir. $O$ halde eleştirel sosyolojik perspektifi, ötesini görme, iç yüzünü anlama, görünenlerin ardına bakma, işin sırrını açığa çıkarma olarak anlamak mümkündür. Esasen sosyal sırlar görünen yüzlerin ardındadır. Bu sırlara nüfuz etme isteği, sosyolojik merakın da özünü oluşturur. İşte bu yüzden eleştirel sosyolojik düşünmeyi, Friedrich Nietzsche'nin (Akt: Berger, 2018, s. 45) "şüphe sanatı" dediği şeyin bir parçası olarak görmek yanlış olmaz.

Öğrencilerin toplumu farklı açılardan anlama becerilerine sahip olmalarını sağlama gayesi sosyoloji eğitiminin tam kalbinde yer almaktadır. Bu, bir perspektiften diğerine geçme becerisini, Mills'in (2016) "sosyolojik tahayyül" dediği zihinsel vasfı kazandırma çabasıdır. Çünkü eleştirel düşünebilmeleri için öğrencilere kılavuzluk etmek, onların kişisel gerçekliği geniş çaplı toplumsal gerçeklikle bağlantılı olarak anlamalarına yardımcı olmak demektir. Yükseköğretim kurumlarının giderek artan bir oranda teknisyen imal etmeye yöneldiği bir zamanda, düşüncelerinde tarihsel ve toplumsal yapı fikrinden faydalanan, problemleri ortaya çıkaran yapisal koşulları anlayan ve bunlarla yüzleşen, sosyolojik muhayyilesi geniş bireyler yetiştirmek oldukça önemlidir. Müstakbel sosyologları bir teknisyenden ayırt edecek olan da kuşkusuz bu hayal gücüdür.

Tarihin korkunç şekillenme hızında, insanlar çoğu zaman eski duyumsama ve düşünme tarzlarının çöktüğünü ve yeni başlangıçların da ahlâki açıdan felç edici derecede müphem olduğunu hissetmekte (Mills, 2016, s. 15). Baş döndürücü hızda değişen ve bilginin muazzam boyutlara vardığı öyle bir dünyada yaşamaktayız ki yeni bilgilerin arttığı oranda eskileri geçerliklerini yitirmekte. İnsanların bu sürekli değissim ivmesiyle başa çıkıp içinde yaşadıkları dönemde kendi yaşamlarını anlamlandırabilmeleri için mevcut bilgiyi sorgulama ve analiz etme konusunda ehil olmaları gerekmekte. İşte dünyada olup bitenlere ilişkin bir anlayış geliştirmemizi sağlayan sosyolojik perspektif, bizi eleştirel düşünmeye teşvik eder; olağan ve kaçınılmaz olduğu düşünülen şeylerin altında yatan toplumsal yapıyı ve güçleri açığa çıkarmak için sorulmamış soruları sormaya kışkırtır. Eleştirel sosyolojik düşünme sanatını öğrenip onda ustalaşan birey kuşkusuz daha az manipüle edilebilir, dışarıdan gelen baskı ve dayatmalar karşısında kendini daha güçlü hisseder.

Sosyolojide eleştirel düşünme, insan eylemlerinin amaçlarına dair çoklukla kabul edilen ya da resmi olarak tanımlanan noktaların ötesine bakma yeteneğini ve toplumsal olayların farklı anlam düzeylerine sahip olduğuna dair belirli bir bilinci gerektirir. Görünümlerin ardındaki gerçekliği görmek içinse ciddi bir entelektüel çaba lazımdır. İște bu nedenle Alfred Schutz’un (Akt: Berger, 2018, s. 37) özlü ifadesindeki gibi "Dünyayı olduğu gibi kabul eden insanlar sosyolojiye bulaşmamalıdır." 
Birçok sosyolog, sosyoloji sınıflarında eleştirel düşünmeye yönelik çabaların ihmal edildiği konusunda mutabıktır (Browne ve Litwin, 1987, s. 384). Öğretimde odak noktası olarak eleştirel düşünmeye verilen desteğe rağmen hedefe ulaşmak için çok az çaba harcanmaktadır (Baker, 1981, s. 359). Sosyologlar, eleştirel düşünmeyi öğrenmenin değerini anlamış ve birçoğu öğrencilerin bu alanda gelişimini cesaretlendirmek için çeşitli öğretim stratejileri geliştirmiştir; ancak pek azı eleştirel düşünmeyi ampirik olarak test etmiştir. Hatta bu konudaki kuramsal açıklamalar da oldukça yetersizdir ve eleştirel düşünme kavramı muğlaklığını korumaktadır (Grauerholz ve Bouma-Holtrop, 2003, s. 488).

Madem sosyologlar eleştirel düşünmeyi müfredat hedeflerinde en üst sıralara yerleştiriyorlar, sosyolojiye özgü eleştirel düşünme ile ilgili kavramsal ve kuramsal bilgiler neden yetersiz ve eğitimle ilgili böylesi bir kazanımı değerlendirmek üzere tasarlanmış ampirik araştırma neden yok denecek kadar az? Baker'n (1981, s. 326) yönelttiği bu retorik soru, sosyoloji eğitiminde henüz keşfedilmemiş alanları keşfetme ihtiyacına dikkat çekmektedir.

Peki, eleştirel sosyolojik düşünme neyi ihtiva etmektedir? Sosyologlar, eleştirel düşünmeyi nasıl kavramsallaştırmakta ve ölçmektedir? Bu çalışma, sosyolojideki lisans öğrencilerinin toplumsal konularla ilgili eleştirel düşünme becerilerini ölçmeyi ve bölümün olağan müfredatı içerisinde eğitim aşamaları, yani sinıflar ilerledikçe bu becerilerin bir gelişim gösterip göstermediğini ya da ne düzeyde geliştiğini test etmeyi amaçlamaktadır. Çalışma ayrıca, sosyolojiye özgü eleştirel düşünme konusundaki mevcut bilgileri inceleyerek eleştirel sosyolojik düşünme kavramını belirginleştirme gayesindedir.

Eleştirel düşünmeyi ölçme konusunda kayda değer çalş̧malar bulunmakla birlikte, kullanılan değerlendirme araçları çoğunlukla sosyologlarca geliştirilmediğinden bu çalışmalar spesifik olarak sosyolojik içerikle ilgili değildir. Dolayısıyla literatürde sosyolojiye dair eleştirel düşünme becerilerini ölçme girişiminde bulunan az sayıda araştırma bulunmaktadır. Türkiye'de ise sosyoloji disiplinine özgü eleştirel düşünmeyi ele alan herhangi bir araştırmaya rastlanmamışır. Bu nedenle, çalışmanın literatürdeki eksikliği gidermeye katkıda bulunacak bir adım olacağı düşünülmektedir. Çalışmanın, sosyoloji disiplini açısından son derece önem atfedilen bir kazanım olan eleştirel düşünme becerilerini geliştirmeye yönelik çabaların eğitim programlarına dâhil edilmesinde bir referans noktası olması ümit edilmektedir.

\section{Kavramsal Analiz}

Birçok önemli kavram gibi eleştirel düşünmenin de kesin ve kusursuz bir tanımını yapmak güçtür. Terim, sosyolojide müfredat teşebbüslerinin tumturaklı bir gerekçesi olarak epeyce kullanışlı olmuşsa da ampirik incelemesi yapılabilen analitik bir kavram olarak pek ele alınmamıştır (Baker, 1981, s. 359). Aşırı kullanımına rağmen eleştirel düşünmeye dair kavramsal netliğin olmadığını öne süren Geertsen (2003, s. 7), California'da yapılan bir araştırmayı örnek göstererek, yüksekokullardaki öğretim elemanlarının \%89'unun eleştirel düşünmeyi öğretim hedeflerinden biri olarak saymakla birlikte bunların yalnızca \%19’unun bu kavramın ne anlama geldiğine dair tatmin edici açıklama yapabildiğini belirtmektedir. Eleştirel düşünmenin tüm boyutlarını kuşatacak bir şema çizmenin zorluğu, kavramı tanımlama girişimlerinde çeşitliliğe yol açmıştır.

Bu alandaki öncülerden Dewey (Akt: Geertsen, 2003, s. 2), eleştirel düşünmeyi "bireyin problem çözme sürecinde yaptığ muhakemeler" olarak tarif etmektedir. Ennis (1993, s. 180), "Eleştirel düşünme, neye inanacağımıza veya ne yapacağımıza karar vermeye odaklanmış makul, yansıtıcı bir düşünmedir." derken Paul (1992, s. 7), "Eleştirel düşünme, düşündüğünüz esnada düşünmenizi daha iyi bir hale getirmek amacıyla kendi düşündükleriniz hakkında düşünmedir." şeklinde bir tanım yapmaktadır. Lipman’a göre (2003, s. 28) ise, "Eleştirel düşünme, iyi bir yargyya götüren becerili ve sorumlu bir düşünmedir, çünkü içinde bulunduğu bağlama duyarlıdır, kriterler üzerine kurulur ve kendini düzeltici bir yapıya sahiptir."

Tanımlamalardaki farkll1ıklara rağmen birçok uzman eleştirel düşünmenin bilgiyi uygulama, analiz etme ve değerlendirme becerilerini içerdiği hususunda uzlaşmaktadır (Ruminski ve Hanks, 1995, s. 5). Eleştirel düşünme yazınını incelediği çalışmasında Baker (1981, s. 328), eleştirel düşünmenin genelde iki yöntemle, i) problem çözme süreci olarak, ii) tümdengelimli mantık ve argüman analizi süreci olarak kavramsallaştırıldığını söylemektedir. Green ve Klug (1990, s. 465) ise, eleştirel düşünmenin sorunları netleştirme, mantık hatalarını saptama ve değer varsayımlarını tanımlama gibi mikro düzey entelektüel becerileri; ne yapılacağına veya neye inanılacağına ilişkin nedenler aramaya yönelik iştiyak, şüphecilik, kanıt arama, yaratıcılık, kendi önyargılarına ve değerlerine karşı tetikte olma gibi makro düzey eğilimleri; açı fikirlilik, empati, özeleştiri ve adalete bağlılık gibi makro düzey değerleri içerdiğini vurgulamaktadır. 
Geertsen (2003), eleştirel düşünmeyi kavramsallaştırmaya çalısırken Dewey’in yaptı̆ğ gibi eleştirel düşünme ile yansıtıcı düşünmeyi birbirinden ayırmaktadır. $O$, eleştirel düşünme ve yansıtıcı düşünme kavramlarını olağan düşünmeden farkl, daha disiplinli ve sistematik bir düşünme biçimini temsil eden "üst düzey düşünme" terimi altında birleştirmektedir. Üst düzey düşünmeyi ise, mevcut bilgiyi doğrulamak için zihnin disiplinli ve sistematik bir kullanım şekli ya da çeşitli soyutlama düzeyleri vasıtasılyla yeni bilgileri araştırmak olarak tanımlamaktadır. Mevcut bilgilerin doğrulanması üst düzey düşünmenin eleştirel yönü iken yeni bilgi arayışı üst düzey düşünmenin yansıtıcı yönüdür.

Shepelak, Curry-Jackson ve Moore (1992, s. 20), eleştirel düşünmeye dair özellikle sosyoloji müfredatına uygun bir kavramsal çerçeve geliştirmiştir. Oluşturdukları model, eleştirel düşünmeyi bir dizi aşama olarak görmektedir. İlk aşama, mevcut bilgi ve beyanların anlaşılmasını gerektirmektedir. Bu aşama, başka bir kişinin beyanlarının ve fikirlerinin anlamının tamamen kavranabilmesi için dikkatli gözlem, dinleme ve okuma becerilerinin geliştirilmesini zorunlu kılar. İkinci aşamada, bilgi ve beyanlar değerlendirilmektedir. $\mathrm{Bu}$ aşamada, varsayımları, belirsizlikleri ve nedensel çıkarımdaki sorunları belirledikten sonra kişi, diğerlerinin görüşüne katılmaya veya katılmamaya karar verir. Üçüncü aşamada kişi, değerlendirmesinin nedenlerini açıklamalıdır. Bu noktada maksat, kişinin düşünsel pozisyonunu sıradan akıl yürütmeden ziyade üst düzey muhakemeyle destekleyebilmesidir. Son olarak dördüncü aşamada yaratıcı bir açıklama yapılır. Bu noktada, savunulabilecek mantıklı, ampirik bir açıklama geliştirilir.

Eleştirel düşünme, bilginin aktif ve makul olarak değerlendirilmesine yönelik bilişsel bir yaklaşım olarak görülmekte (Browne ve Litwin, 1987, s. 384) ve argümanların rasyonel bir şekilde incelenmesine izin veren bir dizi mantıksal analizin farkındalığına ve anlaşılmasına dayanmaktadır (Ennis, 1989, s. 4). Başkalarının savlarını anlamak ve eleştirel olarak değerlendirmek için bireylerin bir dizi analitik soru sormaları gerekmektedir. Bu soruların nasıl sorulacağ bilgisi, soru sorma ve cevaplama arzusu eleştirel sorgulamanın başlangıç noktasını teşkil etmektedir (Shepelak vd., 1992, s. 20).

Bazı bilim adamları, genel olarak eleştirel düşünme becerilerinin herhangi bir konuya ya da soruna uygulanabileceğini iddia ediyorsa da (Wade ve Tavris, 1993; Paul, 2012), diğer bir kısmı (McPeck, 1990; Geertsen, 2003; Nosich, 2016) farklı disiplinler için belirli düşünme kabiliyetlerinin daha gerekli olduğuna inanmaktadır. Çünkü her disiplin dünyaya kendine özgü bir bakış açısı sağlamaktadır. Mesela sosyolojinin bakış açısı, coğrafyanın, biyolojinin veya psikolojinin bakış açılarından farklıdır. Her disiplin, dünyayı daha odaklanmış bir biçimde görebileceğimiz bir lens takımı olarak işlev görür. Bir disiplinin bakış açısı öylesine derinlere uzanır ki o disiplindeki kişiler bizim baktığımızdan çok farklı bir dünyaya bakıyorlar gibi gözükür (Nosich, 2016, s. 115). McPeck (1990), eleştirel düşünmenin belirli bir branşın alanı dışında öğretilemeyeceğini savunmaktadır. Zira bir alanda eleştirel düşünmek, o alanın mantığını kavramayı, olayları o alandaki kavramlarla düşünmeyi gerektirir (Nosich, 2016, s. 98). McPeck'e göre (1990) eleştirel düşünme, bir bilgi bileşenini (disipline dayalı bilgi ve becerileri) ve bir eleștirel bileşeni (söz konusu bilgiyi yansitma ve sorgulama yeteneği) içerir. Dolayısıyla sosyolojiye özgü eleştirel düşünme, başka bir disipline özgü eleştirel düşünmeyle aynı şey veya onun bir parçası değildir.

Üst düzey düşünmenin altı boyutunu tanımlayan Geertsen (2003, s. 10), sosyoloji disiplinine özgü düşünme tarzının bu boyutlardan biri olan "referansal düşünme" ile ilişkili olduğunu ileri sürmektedir². Referansal düşünmenin bir ayağı; birden çok örneği tanımlamayı, örneklerin ortak yönlerini çözümlemeyi, örnekleri örnek olmayanlardan ayırt etmeyi ve temel kavramsal yapıyı belirlemeyi içeren bir eleştirel öğrenme süreci olan "kavramsallaştırma"dır. Nosich (2016, s. 39), bir disiplinde eleştirel düşünmek için ilgili alanın temel ve güçlü kavramlarının derin bir biçimde öğrenilmesinin zorunlu olduğu fikrindedir. Söz gelişi, sosyoloji disiplininde insanların bir soruya ne kadar iyi bir mantıkla yaklaştıklarını incelemenin yolu sosyal yapılar kavramına odaklanmaktır.

Referansal düşünmenin diğer ayağı, hâlihazırdaki bir sorun ile daha geniş toplumsal bağlamlar arasındaki bağlantıların belirlenmesini ifade eden bir yansıtıcı düşünme süreci olan "bağlamsallaş̧ırma"dır. Bağlamsallaştırma, belirli bir kavramın temel tanımlayıcı niteliklerini korurken farklı bağlamlarda çok katmanlı anlamlar üstlenebileceğini örnekler kullanmak suretiyle gözler önüne sermektir (Geertsen, 2003, s. 13). Nosich'e göre (2016, s. 66), bir şey hakkında mantıklı bir biçimde düşünürken bunu soyutlanmış bir ortam içerisinde yapmayız. Derinlemesine düşünmemiz her zaman bir bağlam içerisinde olur ve konuyla alakalı soru her zaman o bağlam içerisinde oluşur. Bu görüşe paralel bir biçimde Brookfield (1997, s. 17),

\footnotetext{
2 Geertsen'e göre üst düzey düşünmenin referansal düşünme dışındaki boyutları; stratejik düşünme, değerlendirici düşünme, bilimsel düşünme, refleksif düşünme ve kıyaslamalı düşünmedir.
} 
eleştirel düşünmenin toplumsal olarak inşa edilmiş ve doğası gereği bağlamsal bir süreç olduğuna inanmaktadır. Ona göre eleştirel düşünme yalnızca belirli bağlamlarda değerlendirilebilir.

Geertsen (2003, s. 13), bağlamsallaştıma kavramının birçok kişisel sıkıntının çözüme kavuşturulmamış kamusal sorunların belirtileri olduğunu görmemizi sağlayarak dikkati büyük resme çektiğini ifade etmek suretiyle Mills'in sosyolojik tahayyül kavramına atıfta bulunmaktadır. Nitekim Mills (2016, s. 181), “Toplumsal bütünün herhangi bir hususi niteliğinin incelenmesinde özel olarak 'sosyolojik' olan şey, bütüne ilişkin bir kavrayış kazanmak için bu hususi niteliği diğerleriyle ilişkilendirme yönündeki aralıksız çabadır." diyerek sosyolojik tahayyülün büyük oranda bu tür bir çabanın ürünü olduğunu vurgulamaktadır. Başka sosyologlar da, eleştirel düşünme ile Mills’in sosyolojik tahayyül kavramı arasındaki bağlantının altını çizmektedir (Grauerholz ve Bouma-Holtrop, 2003, s. 487). Örneğin Green ve Klug (1990, s. 462), eleştirel düşünmenin sosyolojik tahayyüle dayanan mantıksal argümanlar oluşturmayı ve bu argümanları ampirik olarak desteklemeyi içerdiği görüşündedir. Bidwell (1995, s. 401) ise sosyolojik tahayyülün, bireylerin toplumsal olayları eleştirel bir biçimde değerlendirerek kendi yaşamlarıyla ilişkilendirmelerine yardım eden bir zihinsel vasıf olarak dünyaya bakmanın eşsiz bir yolu olduğunu söylemektedir.

Grauerholz ve Bouma-Holtrop (2003, s. 493), herhangi bir konuya ya da probleme uygulanabilir baz1 temel eleştirel düşünme becerilerinin var olabileceğini yadsımaksızın, sosyolojide eleştirel düşünmenin başka disiplinlerdeki eleştirel düşünmeden farklı beceriler gerektirdiğini savunmaktadırlar. Bu nedenle, McPeck'in (1990) "disipline özgü eleştirel düşünme” anlayışıyla tutarlı ve aynı zamanda Geertsen’in (2003) hem eleştirel düşünmeyi hem de yansıtıcı düşünmeyi kuşatan "referansal düşünme" kavramını temel alan "eleştirel sosyolojik düşünme" kavramını kullanmayı önermektedirler. Bu kavram, sosyal dünya hakkında muhakeme yürütmede sosyolojik bilginin ve sosyolojik tahayyülün önemini açıkça vurgulamaktadır. Eleştirel sosyolojik düşünme; sosyolojik bilgi ve becerileri, bu bilgiyi sosyal olgular üzerine düşünürken, onları sorgularken ve yargıda bulunurken kullanma kabiliyetini, sosyal ve kültürel bağlama duyarlığ1 ve farkındalığı gerektirmektedir. Kavramsal değerlendirme ve bağlamsal değerlendirme gibi Geertsen (2003) tarafindan tarif edilen düşünme türlerinin bir bileşimini kapsayan eleştirel sosyolojik düşünme, disipline özgü bir eleştirel düşünmedir. Grauerholz ve Bouma-Holtrop’un (2003, s. 493) altını çizdiği üzere, bu düşünme tarzında, öğrenciler, bireysel yaşam tercihlerinin, koşulların ve sorunların ırk, cinsiyet, sosyal sınıf ve sosyal kurumlar gibi toplumsal güçler ya da toplumsal yapı tarafindan şekillendirildiğini anlarlar.

\section{Yöntem}

$\mathrm{Bu}$ çalışma, nicel araştırma yöntemlerinden biri olan betimsel araştırma modeline göre gerçekleştirilmiştir. Bir olguyu ya da olayı olduğu gibi araştırmayı, var olan durumu belirlemeyi amaçlayan betimsel araştırmalar, söz konusu olgunun/olayın "neden" gerçekleştiği ile ilgili sorulardan ziyade "ne" sorusuna cevap arayarak olgunun/olayın niteliklerini ortaya koymaya çalşsır (Ethridge, 2004, s. 24). Çalışmada, olasıllık temelli olmayan örnekleme yöntemlerinden uygun örnekleme yöntemi kullanılmış̧ır. Uygun örneklemede, katılımcılar ulaşması kolay, araştırma için uygun ve gönüllü bireylerden seçilmektedir (Gravetter ve Forzano, 2012, s. 141). Bu çalışmanın hedef evrenini Türkiye'deki üniversitelerin sosyoloji bölümlerinde öğrenim gören lisans öğrencileri oluştururken, örneklem evreni, 2018/2019 eğitim-öğretim yll bahar yarıyllında Adıyaman Üniversitesi Fen-Edebiyat Fakültesi Sosyoloji Bölümü'nde kayıtlı olan 279 lisans öğrencisidir. Örneklem evreninden çalışmaya gönüllü olarak katılan 121 öğrenci örneklemi oluşturmuştur. Katılımcıların 40’1 birinci sınıf, 34’ü ikinci sınıf, 20'si üçüncü sınıf ve 27'si dördüncü sinıf öğrencisidir.

Öğrencilerden, eleştirel sosyolojik düşünme beceri düzeylerini belirlemek amaciyla tasarlanmış bir konuda kompozisyon yazmaları istenmiş ve araştırmanın verileri bu kompozisyonlardan sağlanmıştır. Kompozisyon yazmak düşünceyi berraklaştırmada oldukça etkili bir araçtır. Çünkü yazma eylemi sadece bildiklerini açılamanın bir yolu değildir; aynı zamanda düşünce üretmenin, keşfetmenin ve öğrenmenin eşsiz bir yoludur. $\mathrm{Bu}$ nedenle, öğrencilerin sosyolojik tahayyüllerinin genişlemesini isteyen sosyologlar, onları kişisel deneyimler ve sosyal olaylar hakkında eleştirel düşünmeye sevk edecek yazı ödevleri tasarlamalıdırlar (Bidwell, 1995, s. 401). Literatürdeki birçok çalışma, öğrencilerin eleştirel düşünme becerilerini kompozisyon, deneme, makale gibi yazma ödevlerinden elde edilecek verilerle ölçmenin çoktan seçmeli testlere nazaran daha etkili bir yöntem olduğunu savunmaktadır (Browne ve Litwin, 1987; Ennis, 1993; Geertsen, 2003). Ennis'e göre (1993, s. 181), bazı eleştirel düşünme becerileri çoktan seçmeli testlerle ölçülebilse de bu testler kapsayıcı değildir ve genellikle eleştirel düşünmede önemli olan birçok şeyi gözden kaçırmaktadır. Oysa değerlendirmesi zahmetli de olsa kompozisyon şeklindeki uygulamalar daha kapsamlı 
ve geçerlidir. Leming (1998) ve Montgomery (2002) ise, kompozisyonlardan elde edilecek verileri değerlendirirken dereceli puanlama anahtarlarından faydalanmanın eleştirel düşünmeyi ölçmenin en güvenilir yolu olduğu görüşündedirler.

Ennis (1993, s. 185) eleştirel düşünme becerilerini ölçmek için veri kaynağı olarak kullanılacak kompozisyonların tasarlanmasında üç yaklaşımdan söz etmektedir. Bunlar; i) yü̈ksek seviyede yapılandirlmıs kompozisyonlar, ii) orta seviyede yapulandrrlmus kompozisyonlar ve iii) minimal seviyede yapulanderlmıs kompozisyonlar şeklindedir. Bu çalışmada öğrencilere verilen kompozisyon minimal seviyede yapılandırılmıştır. $\mathrm{Bu}$ yaklaşımda kompozisyon, cevaplanması gereken tek bir soruyu ya da ele alınması gereken tek bir konuyu içermektedir. Puanlamada ise hem bütünsel yani genel bir başarı puanı hem de analitik yani her boyut için ayrı başarı puanı vermek mümkündür.

Bu çalş̧madaki kompozisyonun konusu tüm sınıflar için aynı olup, toplumsal yapı kavramı ve toplumsal yap1 dâhilinde gerçekleşen olaylar açısından sahici öneme sahip bir sosyal problem olması nedeniyle seçilmiştir. Öğrencilere yazmaları için 60 dakika süre verilen kompozisyonun konusu şudur:

'Küresel olarak yaygin bir olgu olan 'kadina yönelik siddet', ülkemizin de en önemli toplumsal sorunlarndan biridir. Dünya üzerinde kadmlar etnik kökeen, din, sinf, statü gözetilmeksizin toplumsal cinsiyyete dayal șiddete maruz kalma riski ile karşı karşyyadrr. Bu bağlamda, Türkiye'nin önemli toplumsal sorunlarnndan biri olan kadina yönelik şiddetin nedenlerini, kökenlerini, onu etkileyen sosyal yapular sosyolojik. bir yaklassmmla analiz. ederek detayl bir şekilde yorumlaymı: Bu toplumsal probleme ilişkin çözümler belirlemeye çalışmı:"

Veri aracı olarak kompozisyon, aynı öğrenciye farklı durumlarda en az iki kez uygulandığında birbiriyle tutarlı veriler elde ediliyorsa yahut da farklı değerlendiriciler/puanlayıcılar tarafından aynı kompozisyonla ilgili bir puanlama cetveline göre yapılan puanlamalar belirli oranda benzerse o veri aracının güvenilir olduğuna inanılmaktadır (Kunkun, 2015, s. 19). Benzerlik oranı araştırmanın güvenirliğini belirlemektedir. Bu çalışmada veri aracı olarak kullanılan kompozisyonlar, biri araştırmacının kendisi olmak üzere iki uzman tarafindan ölçek kullanılarak puanlanmıştır. Öğrencilerin yukarıda belirtilen konu hakkında kaleme aldıkları kompozisyonlardan elde edilen verilerin analizinde Grauerholz ve BoumaHoltrop (2003) tarafindan geliştirilen "Eleştirel Sosyolojik Düşünme Ölçeği’" kullanılmışır. Daha öncesinde, ölçeği geliştiren yazarlardan Elizabeth Grauerholz ile e-posta yoluyla iletişime geçilmiş ve gerekli izin alınmıştır. Ölçeği geliştiren araştırmacılar maddelerin yüksek düzeyde ilişkili olduğunu ve ölçeğin alfa katsayısını 0.95 olarak belirlemişlerdir. İngilizce olan ölçek Türkçeye uyarlanırken ilkin, hem İngilizceye hem de Türkçeye hâkim olan bir akademisyen ve bir çeviri uzmanı tarafindan ölçek maddelerinin çevirisi yapılmıştır. Ardından, yapılan çeviriler araştırmacı ve bir çeviri uzmanı tarafından karşılaş̧ırılmış ve ayrı ayrı her maddeyi en iyi ifade ettiği düşünülen çeviriler benimsenmiştir. Ölçeğe tekrar faktör analizi yapılmış, Kaiser Meyer Olkin (KMO) değeri 0.942 bulunmuştur. Ayrıca tüm maddelerin faktör yüklerinin çok yüksek olduğu ve birbiri ile ilişkili olduğu tekrar test edilmiştir. Çalışmamızdaki ölçeğin ölçüm güvenilirliği ise 0.96 olarak belirlenmiştir.

Ölçek maddeleri 1-5 puan skalasında derecelendirilmiştir. 5 puan yüksek düzeyde bir beceriyi ifade ederken 1 puan oldukça düşük düzey becerileri işaret etmektedir. Her biri eleştirel sosyolojik düşünmenin farklı kriterlerini ifade eden ölçek maddeleri aşağıda belirtildiği gibidir:

1. Örnek kullanma (5=yeterli sayıda; $1=$ hiç örnek kullanılmamış)

2. Örneklerin konuyla ilgisi ve tartışmanın amacına uygunluğu ( $5=$ anlamlı, ilişkili ve uygun; $1=$ anlamsiz, gereksiz)

3. Muhakeme (5=aç1k, tam; $1=$ belirsiz, eksik $)$

4. Önyarg1 (5=önyargiya, hâkim fikirlere ve duygularına asla kapılmamış; $1=$ sıklıkla önyargının, hâkim fikirlerin ve duygularının cazibesine kapılmış)

5. Konuyu iki taraflı ele alma [Madalyonun iki yüzüne de bakma] (5=sıklıkla; farklı bakış açıları ve farklı iddialar sunmuş; $1=$ hiç; konuyu sadece tek taraflı ele almış)

6. Sosyal yapısal bağlamların (sınıf, cinsiyet, yaş, $1 \mathrm{rk}$, din vb.) farkında olma (5=sosyal yapısal bağlamlar net ve anlamlı bir şekilde ifade edilmiş; 1 =sosyal yapısal bağlamlara hiç değinilmemiş)

7. Tarihsel bağlamlara ilişkin farkındalık (5=tarihsel bağlamlardan uygun bir şekilde bahsedilmiş; $1=$ tarihsel bağlam yok sayılmış) 
8. Kültürel farklılıkların bilincinde olma (5= kültürel farkll1ıklar yerinde ve uygun bir şekilde ifade edilmiş; 1=kültürel farkllıklar yok sayılmış)

9. Konuyu analiz etmek ve aydınlatmak için sosyolojik kavramların kullanılması (5=çeşitli sosyolojik kavramlar tam yerinde kullanılmış; $1=$ hiç kullanılmamış)

10. Eleştirel düşünme sergileme ( $5=$ yüksek düzeyde; 1 =yok veya çok alt düzeyde)

11. Sosyolojik tahayyül sergileme (5=kişisel/kamusal bağlantısına dair net bir farkındalık mevcut; $1=$ tamamen bihaber)

Verilerin yorumlanmasında yol gösterici olarak, Turgut ve Baykal (1992) tarafindan önerilen yöntem kullanılmıştır. Buna göre, beceri düzeyleri için puan aralıkları hesaplanırken en yüksek madde puanı ile en düşük madde puanı arasındaki fark seçenek sayısına bölünerek aralıklar elde edilmiştir $[(5-1) / 5=0.80]$. Beceri düzeylerine ilişkin puan ve puan aralıkları Tablo 1'de görülmektedir.

Tablo 1. Beceri Düzeyleri Puan ve Puan Aralkelar

\begin{tabular}{lcc}
\hline Beceri Düzeyleri & Puan & Puan Aralığ1 \\
\hline Çok Yetersiz & 1 & $1,00-1,79$ \\
Yetersiz & 2 & $1,80-2,59$ \\
Orta & 3 & $2,60-3,39$ \\
Yeterli & 4 & $3,40-4,19$ \\
Çok Yeterli & 5 & $4,20-5,00$ \\
\hline
\end{tabular}

Verilerin analizinde test edilen her madde için ayrı ayrı ortalamalar sunulmuştur. Böylece her bir maddeyi kendi içinde değerlendirme imkânı doğmuştur. Ayrıca, ölçekteki tüm maddelerin sınıf bazında genel ortalamaları sunulmuş böylece sürecin bütünsel olarak değerlendirilmesi sağlanmıştır. Ayrıca sınıfların eleştirel sosyolojik düşünme beceri düzeyleri arasında anlamlı bir farklılık olup olmadığını saptamak üzere ANOVA testi, anlamlı değişimin hangi grupta olduğunu bulmak içinse Çoklu Karşılaştırma Testi uygulanmıştır. Gruplar arası varyansların eşit ve grupların örneklem büyüklüğünün ise eşit olmamasından dolayı çoklu karşılaştırma testlerinden biri olan LSD (Least Significant Difference) testi kullanılmıştır.

\section{Bulgular}

Sosyolojideki lisans öğrencilerinin toplumsal konularla ilgili eleştirel düşünme becerilerinin bölümün olağan müfredatı içerisinde eğitim aşamaları, yani sınıflar ilerledikçe bir gelişim gösterip göstermediğine ya da ne düzeyde geliştiğine dair bulgular Tablo 2'de yer almaktadır. Tablo 2, eleştirel sosyolojik düşünmeyi ölçmede kullanılan her bir madde için sınıf bazında ortalamaları (x) göstermektedir.

Tablo 2. Eleștirel Sosyolojik Düsünme Beceri Düzeyleri

\begin{tabular}{|c|c|c|c|c|}
\hline Ölçek Maddeleri & $\begin{array}{c}\bar{x} \\
\text { (1. Sinif) } \\
\end{array}$ & $\begin{array}{c}\bar{x} \\
\text { (2. Sinif) }\end{array}$ & $\begin{array}{c}\bar{x} \\
\text { (3. Sinif) }\end{array}$ & $\begin{array}{c}\bar{x} \\
\text { (4. Sinif) } \\
\end{array}$ \\
\hline [1] Örnek kullanma & 1,60 & 1,88 & 2,10 & 2,51 \\
\hline $\begin{array}{l}\text { [2] Örneklerin konuyla ilgisi ve tartışmanın amacına } \\
\text { uygunluğu }\end{array}$ & 1,65 & 1,91 & 2,15 & 2,88 \\
\hline [3] Muhakeme & 1,70 & 2,00 & 2,20 & 2,81 \\
\hline [4] Önyarg1 & 2,30 & 2,32 & 2,45 & 2,96 \\
\hline $\begin{array}{l}\text { [5] Konuyu iki taraflı ele alma } \\
\text { (Madalyonun iki yüzüne de bakma) }\end{array}$ & 1,52 & 1,76 & 2,00 & 2,62 \\
\hline [6] Sosyal yapısal bağlamların farkında olma & 2,07 & 2,50 & 2,60 & 3,22 \\
\hline [7] Tarihsel bağlamlara ilişkin farkındalık & 1,65 & 1,79 & 2,15 & 2,74 \\
\hline [8] Kültürel farklılıkların bilincinde olma & 1,80 & 2,23 & 2,20 & 2,88 \\
\hline $\begin{array}{l}\text { [9] Konuyu analiz etmek ve aydınlatmak için } \\
\text { sosyolojik kavramların kullanılması }\end{array}$ & 1,97 & 2,11 & 2,60 & 3,14 \\
\hline [10] Eleştirel düşünme (bütünsel) & 1,97 & 2,08 & 2,10 & 2,70 \\
\hline [11] Sosyolojik tahayyül (bütünsel) & 1,50 & 1,70 & 1,85 & 2,44 \\
\hline
\end{tabular}

Tablo 2 incelendiğinde, öğrencilerin toplumsal bir sorunu değerlendirirken konunun etraflica anlaşılmasına ve savlarının desteklenmesine yardımcı olacak örnekler kullanma [Madde 1] hususundaki beceri düzeylerinin eğitim aşamaları ilerledikçe yükseldiği anlaşılmaktadır. Bu maddeye ilişkin ortalama beceri, birinci sınıf öğrencileri için "çok yetersiz" $(\bar{x}=1,60)$ düzeydedir ki bu durum, konuyla ilgili hiç örnek kullanılmadığını ya da sunulan örneklerin hiç uygun olmadığını işaret etmektedir. Aynı maddeye ilişkin 
beceri düzeyi ortalaması ikinci sınıf öğrencileri için $\bar{x}=1,88$; üçüncü sınıf öğrencileri için $\bar{x}=2,10$ ve dördüncü sınıf öğrencileri için $\bar{x}=2,51$ olup belirli bir artış eğilimini ortaya koymaktadır; yine de bu konudaki beceri düzeylerinin "yetersiz" olduğu göze çarpmaktadır.

Öğrencilerin konuyla alakalı ve tartışmanın amacına uygun örnekler verme [Madde 2] bakımından ortalama beceri düzeyleri ise; birinci sınıf öğrencileri için $\bar{x}=1,65$ (çok yetersiz), ikinci sınıf öğrencileri için $\bar{x}=1,91$ (yetersiz), üçüncü sınıf öğrencileri için $\bar{x}=2,15$ (yetersiz) şeklindedir. Dördüncü sınıf öğrencilerinin ise bu madde ile ilgili becerilerinin "orta" düzeyde $(\overline{\mathrm{x}}=2,88)$ olduğu görülmektedir. Eleştirel sosyolojik düşünmenin bu boyutuyla ilgili beceriler de ilerleyen eğitim aşamalarıyla birlikte artmaktadır, ancak nihai aşamada yalnızca "orta" düzeyde bir beceri edinildiği gözlenmektedir.

Tablo 2'ye göre, öğrencilerin muhakeme becerileri [Madde 3] birinci sınıftan itibaren aşamalı olarak artmıştır. Birinci sınıftaki öğrencilerin muhakeme becerileri $\bar{x}=1,70$ ortalama ile "çok yetersiz" düzeydeyken, ikinci sınıf öğrencilerinin $\bar{x}=2,00$ ve üçüncü sınıf öğrencilerinin $\bar{x}=2,20$ ortalama ile muhakeme becerilerinin "yetersiz" düzeyde kaldığ1 müşahede edilmektedir. Son sınıftaki öğrencilerin eleştirel sosyolojik düşünmenin muhakeme boyutunda "orta" düzey $(\bar{x}=2,81)$ becerilere sahip oldukları belirlenmiştir.

Öğrencilerin toplumsal bir meseleyi değerlendirirken önyargılarının etkisinde kalıp kalmadıklarına dair ölçek maddesi [Madde 4] ile ilgili ortalama beceri düzeyleri mercek altına alındığında, birinci sınıf öğrencilerinin diğer maddelere kiyasla daha yüksek bir beceri $(\bar{x}=2,30)$ sergiledikleri ve ikinci sınıf ögrencileriyle neredeyse aynı beceri düzeyi ortalamasına $(\bar{x}=2,32)$ sahip oldukları görülmektedir. Üçüncü sınıf öğrencilerinin ortalama beceri düzeyi ise $\bar{x}=2,45$ 'tir. Bu sınıfların peșin hükümden sakınma ve hâkim fikirlerin ve duygularının cazibesine kapılmaktan kaçınma konusunda "yetersiz" bir beceri düzeyinde bulundukları tespit edilmiştir. Aynı konudaki beceri ortalaması dördüncü sınıflarda biraz daha artmış olsa da $(\bar{x}=2,96)$, "orta" seviyeden ileri gidememiştir.

Tablo 2, öğrencilerin konuyu farklı bakış açılarından değerlendirme ve konuyla ilgili farklı iddiaları sunma [Madde 5] bakımından ortalama becerilerinin aşamalı olarak arttı̆̆ını göstermektedir. Birinci sınıf $(\bar{x}=1,52)$ ve ikinci sinıf $(\bar{x}=1,76)$ öğrencilerinin bu madde ile ilgili becerileri "çok yetersiz", üçüncü sınıf öğrencilerinin $(\bar{x}=2,00)$ "yetersiz" ve dördüncü sınıf öğrencilerinin $(\bar{x}=2,62)$ "orta” düzeydedir.

Çalışma neticesinde elde edilen bulgular, birinci sınıf ve ikinci sınıf öğrencilerinin bir konuyu incelerken sosyal yapısal bağlamlara [Madde 6] ilişkin "yetersiz" düzeyde bir farkındalık gösterdiklerini ortaya koymaktadır. Sirasiyla $\bar{x}=2,07$ ve $\bar{x}=2,50$ olan ortalama beceri düzeyleri, bu sinifların konunun sosyal yapısal bağlamlarına çok az değindiğini, diğer bir ifadeyle konuyu, onu etkileyen sosyal güçlerin ve içinde şekillendiği toplumsal bağlamın bilinciyle değerlendirme becerisine yeterince sahip olmadıklarını işaret etmektedir. Yine de ikinci sınıfların $\bar{x}=2,50$ olan ortalama beceri düzeyi, eleştirel sosyolojik düşünmenin diğer göstergelerindeki beceri düzeylerine kıyasla daha yüksek görünmektedir. Üçüncü sınıfların sosyal yapısal bağlamaların farkındalığına ilişkin ortalama becerisi "orta" düzeydedir $(\bar{x}=2,60)$ ve eleștirel sosyolojik düșünmenin diğer göstergelerinde sahip oldukları beceri düzeylerine göre daha yüksektir. Dördüncü sinıflar da eleştirel sosyolojik düşünmenin göstergeleri içinde en yüksek beceri ortalamasını $(\bar{x}=3,22)$ bu maddede yakalamışlar (orta), ancak yaklaşmış olmakla birlikte yeterli seviyeye ulaşamamışlardır.

Çalışmaya katılan birinci sınıf ve ikinci sınıf öğrencilerinin analiz edilen konunun tarihsel bağlamına ilişkin farkındalıkları [Madde 7] "çok yetersiz" düzeyde kalmıştır. Bu maddeyle ilgili gösterdikleri ortalama beceri düzeylerinin sırasıyla $\bar{x}=1,65$ ve $\bar{x}=1,79$ olması konunun tarihsel bağlamının yok sayıldığını açığa çıkarmaktadır. Bahsedilen becerinin düzeyi üçüncü sınıflarda belirgin bir şekilde artmışsa olsa da $(\bar{x}=2,15)$ "yetersiz" seviyede kalmıştır. Benzer bir artış dördüncü sınıflar için de $(\bar{x}=2,74)$ geçerlidir; ancak elde edilen "orta" düzey beceri, bu sınıfin konunun tarihsel bağlamından uygun bir şekilde bahsettiğini söylemeyi güçleştirmektedir.

Eleştirel sosyolojik düşünmenin bir diğer göstergesi olan kültürel farkllıkların bilincinde olup konuyu bu bağlamda değerlendirebilme [Madde 8] becerileri mercek altına alındığında, birinci sınıftakilerin $\bar{x}=1,80$, ikinci sinıftakilerin $\bar{x}=2,23$ ve üçüncü sinıftakilerin $\bar{x}=2,20$ ortalama beceri düzeyi ile "yetersiz" bir performans sergiledikleri göze çarpmaktadır. Verilerde bu sınıfların konunun kültürel bağlamının veya kültürel farklılıkların ayrımında olduklarına dair yeterli emare bulunamadığı anlaşılmaktadır. Buradaki dikkat çekici bulgu, ikinci sınıfların bu madde ile ilgili ortalama beceri düzeylerinin üçüncü sınıflarınkinden 
az da olsa yüksek olmasıdır. Son sınıftaki katılımcıların ise yine, bu madde ile ilgili nispeten daha yüksek $(\bar{x}=2,88)$ bir beceri düzeyine (orta) sahip oldukları görülmektedir.

Tablo 2'ye bakıldığında, konuyu analiz etmek ve aydınlatmak için sosyolojik kavramların kullanılması konusunda [Madde 9], birinci sinıftaki katılımciların $\bar{x}=1,97$, ikinci sınıftakilerin ise $\bar{x}=2,11$ ortalama beceri puanı ile "yetersiz" seviyede oldukları görülmektedir. Bu madde ile ilgili beceri düzeyi belirgin bir artışla üçüncü sinıftakilerde $\bar{x}=2,60$ ve dördüncü sinıftakilerde $\bar{x}=3,14$ olmuş, ancak "orta" seviyenin üzerine çıkamamıştır.

Eleştirel düşünmenin genel ölçütlerini göz önünde bulundurarak elimizdeki verilerde eleştirel düşünmeye [Madde 10] dair ipuçlarının izini sürdüğümüzde, birinci sınıftaki katıllımcıların bu boyutla ilgili beceri ortalamasının $\bar{x}=1,97$ ile "yetersiz" düzeyde olduğunu görmekteyiz. Üst sınıflara doğru gidildikçe genel eleştirel düşünme beceri ortalaması, ikinci sinıftakilerde $\bar{x}=2,08$ 'e (yetersiz), üçüncü sinıftakilerde $\bar{x}=2,10$ 'a (yetersiz) ve dördüncü sinfftakilerde $\bar{x}=2,70$ 'e (orta) yükselmekle birlikte arzu edilen düzeyin altında kalmaktadır.

Tablo 2'ye bakıldığında öğrencilerin, sosyolojik tahayyül [Madde 11] göstergesi olan kişisel sıkıntıkamusal sorun bağlantısına dair bir farkındalık sergileyemedikleri anlaşılmaktadır. Bu boyuttaki ortalama beceri düzeyleri, birinci sınıftakilerde $\bar{x}=1,50$ (çok yetersiz), ikinci sınıftakilerde $\bar{x}=1,70$ (çok yetersiz), üçüncü sınıftakilerde $\bar{x}=1,85$ (yetersiz) ve dördüncü sınıftakilerde $\bar{x}=2,44$ (yetersiz) şeklindedir. Eğitim aşamaları ilerledikçe sosyolojik tahayyül gücünün arttığı görülmekle birlikte tüm sinıflarda, ölçek maddeleri içindeki en düşük beceri düzeyi bu maddede ortaya çıkmıstır.

Öğrencilerin bölümün olağan müfredatı içerisinde eğitim aşamaları, yani sınıflar ilerledikçe eleştirel sosyolojik düşünme becerilerinin ne yönde değiştiğini daha açık bir biçimde gösterebilmek için Şekil 1'de beceri düzeylerinin sınıf bazındaki genel ortalamaları [11 maddenin ortalaması] sunulmaktadır.

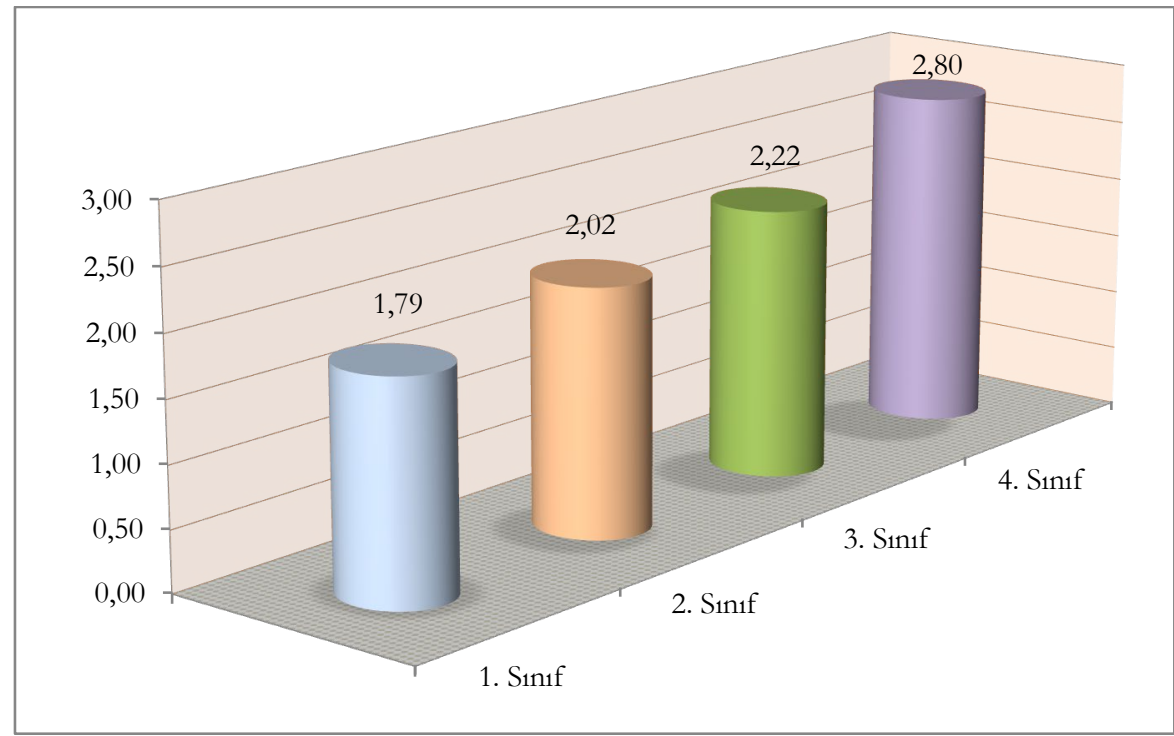

Şekil 1. Eleştirel Sosyolojik Düsünme Beceri Düzeylerinin Genel Ortalamalar

Ölçekteki tüm maddelerin sınıf bazında genel ortalamasına bakıldığında, ilk sınıftan itibaren eleştirel sosyolojik düşünme beceri düzeyinin istikrarlı bir şekilde arttığ1 görülmektedir. Özellikle dördüncü sınıflarda bu artış daha belirgindir. Eleştirel sosyolojik düşünme beceri düzeyi genel ortalaması birinci sınıftakiler için $\bar{x}=1,79$ (çok yetersiz) iken, ikinci sınıftakilerde $\bar{x}=2,02$ (yetersiz), üçüncü sınıftakilerde $\bar{x}=2,22$ (yetersiz), son sinıftakilerde ise $\bar{x}=2,80$ (orta) olarak gerçekleşmiştir. Tespit edilen sürekli artı̧̧a rağmen, nihayetinde öğrencilerin mezun olurken eleştirel sosyolojik düşünme becerilerinin beklenen düzeye ulaşamadığı anlaşılmaktadır.

Son olarak çalışmada sınıflar arasında öğrencilerin eleştirel sosyolojik düşünme beceri düzeylerindeki artışın anlamlı olup olmadığını belirlemek amacıyla tek yönlü ANOVA analizi yapılmıştır. 
Tablo 3. Eleștirel Sosyolojik Düsünme Beceri Düzeylerine İlişkin ANOV A Testi Sonuclar

\begin{tabular}{lcccccc}
\hline Varyansın Kaynağ1 & $\begin{array}{c}\text { Kareler } \\
\text { Toplami }\end{array}$ & sd & $\begin{array}{c}\text { Kareler } \\
\text { Ortalamas1 }\end{array}$ & F & p & $\begin{array}{c}\text { Anlaml1 } \\
\text { Fark }\end{array}$ \\
\hline Gruplar arasi & 17,54 & 3 & 5,847 & 13,784 & .00 & $1-4$ \\
Gruplar içi & 49,626 & 117 & 0,424 & & & $2-4$ \\
Toplam & 67,166 & 120 & & & \\
\hline
\end{tabular}

$\eta^{2}=0,261$

Tablo 3'de görüldüğü gibi öğrencilerin eleştirel sosyolojik düşünme beceri düzeyleri arasında anlaml bir farklılık vardır $\left(\mathrm{F}_{(3)}=13,784, \mathrm{p}<0.05\right)$. Eleștirel sosyolojik düşünme beceri düzeylerindeki anlamlı değişimin hangi grupta olduğunu bulmak amacıyla LSD Çoklu Karşılaştırma Testi yapılmıştır. Birinci sınıfla dördüncü sınıf arasında dördüncü sınıf lehine, ikinci sinıfla dördüncü sinıf arasında yine dördüncü sınıf lehine anlamlı bir farklılık belirlenmiştir. Etki büyüklüğünün $\eta^{2}=0,261$ olarak belirlendiği ve bunun da yüksek seviyede bir etkiye işaret ettiği görülmüştür.

\section{Sonuç, Tartışma ve Öneriler}

Eleştirel sosyolojik düşünme becerilerini 11 boyutta değerlendiren çalışmanın bulguları, öğrencilerin beceri düzeylerinin bölümün olağan müfredatı içerisinde sınıflar ilerledikçe hem boyutların her birinde hem de genel açıdan sürekli bir artış gösterdiğini ortaya koymuştur. Yine de öğrencilerin eleştirel sosyolojik düşünme becerilerinin istenen düzeye ulaştığını söylemek güçtür. Logan (1976) tarafindan yarı deneysel bir desenle gerçekleştirilen bir araştırmada ise, sosyoloji öğrencilerinin toplumsal konular hakkında eleştirel düşünme eğilimlerinin ve becerilerinin bölümün olağan müfredatı içerisinde eğitim aşamalarına bağlı olarak artmadığ1 sonucuna ulaşılmıştır. Söz konusu araştırmada, sosyoloji öğrencilerinin eleştirel düşünme eğilimlerini ve becerilerini ölçmek üzere yirmi maddelik -her biri sosyal olgular hakkında eleştirel olmayan düşünmenin örneği olan kısa ifadelerden oluşan- bir ölçek kullanılmıştır.

Çalışmamızda, öğrencilerin toplumsal bir sorunu değerlendirirken konunun etraflıca anlaşılmasına ve savlarının desteklenmesine yardımcı olacak örnekler kullanma [Madde 1] hususundaki beceri düzeylerinin eğitim aşamaları ilerledikçe yükseldiği ancak bu konudaki becerilerinin "yetersiz" seviyede kaldığı sonucuna ulaşılmıştır. Konuyla alakalı ve tartışmanın amacına uygun örnekler verme [Madde 2] bakımından da beceri düzeylerinin giderek artmakla birlikte nihai aşamada yalnızca "orta" düzeyde bir beceri edinildiği anlaşılmıştır. Toplumsal meselelerle ilgili fikirlerimizin daha net anlaşılabilmesi için konuya dair iyi seçilmiş bir örnek vermek son derece önemlidir. Kullanacağımız örnekler, ne dediğimizi açıklayacak, ifadelerimizi somutlaştıracak nitelikte olmalıdır. Hatta bazen konunun daha iyi anlaşılması için karşıt bir örnek vermek daha yararlı olabilmektedir. Mills (2016, s. 289), toplumsal sorunları eleştirel sosyolojik bir bakış açısıyla ele alırken örnekler sunmanın önemine şu sözlerle dikkat çekmektedir: "Aklınızda en azından esaslı bir örnek bulunmaksızın asla iki-üç sayfadan fazla yazı yazmayın." Öğrencilerin, eleştirel sosyolojik düşünmenin örnek kullanma [Madde 1] ve konuyla alakalı, tartışmanın amacına uygun örnekler verme [Madde 2] boyutlarındaki becerilerinin beklenenden düşük düzeyde olmasının sebebi, sosyoloji bölümlerinin eleştirel düşünmeyi eleştirel yazmaya dönüştürecek bilgi ve becerileri kazandırmada yetersiz kalmaları olabilir. $\mathrm{Bu}$ nedenle sosyoloji programlarında öğrencilere eleştirel yazma becerileri kazandıracak derslere yer verilmesinin faydalı olacağı düşünülmektedir. Nitekim Massengill (2011) tarafindan yapılan bir araştırma, öğrencileri doğru yönlendirecek şekilde yapılandırılmış direktiflerle ve öğretim elemanlarının özenli geri beslemeleriyle oluşturulmuş yazı ödevlerinin, üst düzey düşünme becerilerini geliştirmede etkili olacağ1 sonucuna varmıştır.

Çalışmanın sonuçlarına göre, öğrencilerin muhakeme becerileri [Madde 3] birinci sınıftan itibaren aşamalı olarak artmıştır. Yine de başlangıçtaki "çok yetersiz" seviyenin nihayetinde "orta" seviyeye yükselmiş olması tatmin edici olmaktan uzaktır. Muhakeme, bir konuyu zihinde iyice düşünüp inceleyerek ve akıl süzgecinden geçirerek karar vermektir. Akıl yürütme yoluyla, bilinenler ve kabul edilenler üzerinde düşünüp gerekli incelemeleri yaparak yeni yargilara varma becerisini ifade etmektedir. Muhakeme becerisi, mantıklı ve derinlemesine düşünmeyi gerektirir. Belirli bir konuda muhakeme becerisine sahip olanlar, o konuda yeterli düzeyde bilgiye sahiplerdir ve yeni karşılaştıkları durumları tüm boyutlarıyla inceler, keşfeder, mantıklı tahminlerde, varsayımlarda bulunur, düşüncelerini gerekçelendirir, bazı sonuçlara ulaşır, ulaştıkları sonuçları açıklayabilirler. Bu beceri sayesinde, tartışmasız kabul edilen inançları eleştirel bir gözle masaya yatırmak mümkün olur. Ancak değinildiği üzere, ulaştığımız bulgular, eleştirel düşünmenin olmazsa olmaz bir görünümü olan muhakeme konusunda öğrencilerin genel olarak yeterli beceriye sahip 
olmadıkları yönündedir. Shepelak vd. (1992) tarafından yapılan bir çalışma, sosyoloji öğrencilerinin, takımlar ya da küçük gruplar arası tartışmalarla problem çözmeye odaklanan, oyunlar ve simülasyonlar içeren ve yaratıc1 sorgulamayı teşvik eden aktif öğrenme modellerinin muhakeme becerilerini geliştirmek için kendilerine yeterli fırsatı sağladığına inandıklarını ortaya koymuştur. Benzer bir biçimde, Green ve Klug (1990), yaptıkları bir araştırmada, öğrencilerin toplumsal konulara dair eleştirel düşünme becerilerini ve yazma yeteneklerini geliştirmede tartışmaya dayalı ögretim yönteminin geleneksel öğretim yöntemlerine nazaran daha etkili bir yol olduğu yönünde sonuçlar elde etmişlerdir. Buradan yola çıarak, kesinlik iddiasındaki görüşleri çözümleme ve sorgulama yönünde bir alışkanlık yaratacak şekilde tasarlanmış, aktif öğrenmeye dayalı öğretim modellerinin öğrencilerin muhakeme kabiliyetlerine olumlu etki edeceği düşünülmektedir.

Öğrencilerin toplumsal bir meseleyi değerlendirirken önyargılarının etkisinde kalıp kalmadıklarına dair ölçek maddesi [Madde 4] ile ilgili ortalama becerilerinin illk üç sınıfta "yetersiz" düzeyde olduğu, son sınıfta ise "orta" seviyeden ileri gidemediği belirlenmiştir. Önyarg1 ve toplumdaki egemen fikirlerin cazibesine kapılma, eleştirel sosyolojik düşünmenin önünde zorlu birer engel teşkil etmektedir. Önyargının aşırı biçimleri, kişiyi dünyayı keskin ve uzlaşmaz zıtlara göre algılamaya, farklı görünen her şeye ve herkese derin bir kin beslemeye kadar götürebilmektedir. Bu tip insanlar genelde sabit bir takım fikirlerden sapmaya pek tahammül edemezler. Önyargılardan kurtulmak, kendimizi, ülkemizi, cinsimizi, ırkımızı, politik görüşlerimizi destekleyecek fikirler aramaktan ziyade gerçeği bulmaya yönelik bir kararllık gerektirir. Bu nedenle eleştirel sosyolojik düşünme sürecinde mümkün olduğunca saf dışı edilmesi gereken önyargıların anlaşılma ve kontrol edilme çabası eğitim programlarının bir parçası olmalıdır. Ayrıca eleştirel düşünen sosyoloğun çalıstı̆̆g olguyla ilgili insanların sempatisini artırıp artırmadığına bakmaksızın toplumda genel kabul gören tutumlardan belli ölçüde uzaklaşması gerekir. Çünkü Berger'in (2018, s. 65) çarpıcı bir biçimde ifade ettiği üzere, "Bir fikri saygınlık uyandırması için sahiplenmek kaçınılmaz bir biçimde sosyolojinin ölümü anlamına gelir."

Çalışmamız, ögrencilerin konuyu farklı bakış açılarından değerlendirme ve konuyla ilgili farklı iddiaları sunma [Madde 5] bakımından ortalama becerilerinin aşamalı olarak arttığını, fakat "çok yetersiz" seviyeden başlayan eğrinin ancak "orta" seviyeye varabildiğini ortaya koymuştur. Bu sonuç, öğrencilerin kendi bakış açılarına karşı olan bakış açılarını hesaba katma eğiliminde olmadıklarını gözler önüne sermektedir. Kendi bakış açılarının mutlak doğruluğuna olan inançları farklı yaklaşımları göz ardı etmelerinin sebebi olabilir. Oysa bakış açımızın kendine özgülüğü hakkındaki varsayımımız onun diğer insanların bakış açılarından daha geçerli olduğu anlamına gelmez. Nosich (2016, s. 24), bir konuyu tek taraflı ele almanın, önemli bir eleştirel düşünme davranışı olan adil düşüncenin önünde bir engel teşkil ettiğini vurgulamaktadır. Bauman (2018, s. 283) ise bu konuda şunları söylemektedir: "Sosyolojik düşünmek, en azından, herhangi bir yorumun ayrıcalığına ve kusursuzluğuna duyulan güveni zayıflatır. Deneyimlerin, hayat biçimlerinin çoğulluğunu öne çıkarır... Hayata dair değişik yorumların her biri, olsa olsa kavrayış bütünlüğümüze kendi zenginliğini katacaktır... Dünyaya ilişkin gerçek bir kavrayış özgürlügünün ve hoşgörünün temelinde bu bakış zenginliğinin kabulü yatar."

Çalışmanın neticesi, birinci sınıf ve ikinci sınıf öğrencilerinin bir konuyu incelerken sosyal yapısal bağlamlara [Madde 6] ilişkin "yetersiz", üçüncü ve dördüncü sınıfların ise "orta" düzeyde bir farkındalığa sahip olduklarını gözler önüne sermektedir. Bu sonuç, öğrencilerin konuyu, onu etkileyen sosyal güçlerin ve içinde şekillendiği toplumsal bağlamın bilinciyle değerlendirme becerisine yeterince sahip olmadıklarını işaret etmekle birlikte, eleştirel sosyolojik düşünmenin bu boyutunda diğer göstergelerdeki beceri düzeylerine kıyasla daha yüksek puan aldıklarının altı çizilmelidir. Öğrencilerin sosyal meseleleri formüle ederken sosyoloji disipliniyle sıkı bir biçimde bağlantılı olan toplumsal yap1 fikrinin bilincinde olmaları ve toplumsal çözümlemenin olmazsa olmazının toplumsal yapılara odaklanmak olduğunu bilmeleri zaruridir. Günümüzde kişisel sıkıntılarla birlikte birçok kamusal sorun da psikiyatrik açıdan betimlenir hale gelmiştir ve bu genel olarak modern toplumun büyük problemlerini geçiştirmeye dönük üzücü bir çabanın ürünüymüş gibi gözükmektedir (Mills, 2016, s. 24). Oysa insan, toplumun dişında, yalıtılmış bir varlık olmadığından onun yaşamı, içerisinde şekillendiği kurumlara gönderme yapmaksızın gerektiği şekilde anlaşılamaz. Bauman'ın (2018, s. 23) belirttiği üzere, bireysel olandaki sosyal olanı görebilme, yani bireyin hayat hikâyesi ile sosyal süreçler arasındaki sıkı bağın, bireyin belki farkında olmadığı ve kesinlikle denetleyemeyeceği o bağın keşfi sosyolojinin temel düsturudur. Arzu edilen düzeyde olmasa da, çalş̧maya katılan öğrencilerin sosyal yapısal bağlamların farkındalı̆̆ına dair becerilerinin eleştirel sosyolojik düşünmenin ölçekte yer alan diğer boyutlarına nazaran daha yüksek olması, sosyoloji öğretiminin ilk basamağından itibaren bu temel düsturun merkezi önemde addedilmesinin göstergesidir. Bu durum ayrıca, 
sosyolojinin klasik problemlerini belirli toplumsal yapılara dayanarak formüle etme ve çözümlere bu bağlamda ulaşma eğilimini öğrencilere kazandırmaya yönelik istikrarlı çabaların belirtisi olarak da değerlendirilebilir.

Çalışmaya katılan birinci sınıf ve ikinci sınıf öğrencilerinin analiz edilen konunun tarihsel bağlamına ilişkin farkındalıkları [Madde 7] "çok yetersiz" düzeyde kalmıştır. Bu beceri düzeyi üçüncü sınıflarda belirgin bir şekilde artmışsa olsa da "yetersiz" seviyenin üzerine çıkamamıştır. Benzer bir artış dördüncü sınıflar için de geçerlidir; ancak elde edilen "orta" düzey beceri, konunun tarihsel bağlamından uygun bir şekilde bahsedildiğini söylemeyi güçleştirmektedir. Öğrencilerin tarihsel bağlamsallaştırma yani geçmişin bilgisini belirli durumları anlamlandırmak için kullanma becerilerinin düşük olması, günümüz odaklı bir bakış açısına sahip olduklarını göstermektedir. Oysa sosyolojik perspektif, konunun karşılaştırmalı bir kavrayışını elde etmek için onu tarihsel bir çerçeveye oturtmayı gerektirir. Dolayısıyla her toplumsal inceleme tarihsel bir kavrayış ufkuna sahip olmalı ve tarihsel malzemeden layıkıyla yararlanmalıdır. Aron (2017, s. 26), birçok ünlü sosyoloğun tarihsel veriyi anlamak, tarihsel verinin tutarsız gibi görünen sonsuz çeşitliliğinden düzenli bulgulara ulaşmak için yoğun çaba sarf ettiğinin altını çizmiştir. Zira sosyolojik meselelere tarihsel bir bilinçle yaklaşmayan çalışmaların esaslı problemleri hakkıyla ifade etme şansı bulunmamaktadır. Bu nedenle, sosyal bir meseleyi incelerken hem çağdaş hem de tarihi toplumsal yap1 çeşitliliğini göz önünde bulundurmak gerekmektedir.

Çalışma, ilk üç sınıftaki öğrencilerin, eleştirel sosyolojik düşünmenin bir diğer göstergesi olan kültürel farklılıkların bilincinde olup konuyu bu bağlamda değerlendirebilme [Madde 8] boyutundaki becerilerinin "yetersiz" olduğu sonucunu ortaya koymuştur. Son smnfftaki öğrencilerin bu maddeye ilişkin becerilerinin ise "orta" düzeyde olduğu anlaşılmıştır. Bu sonuç, öğrencilerin genel olarak, kültürel bağlamın veya kültürel farklılıkların yeterince ayrımında olmadıklarını açığa çıkarmaktadır. Oysa eleştirel sosyolojik düşünmeyi şiar edinen öğrencinin toplumsal meseleleri değerlendirirken kendi kültürünün zamanda ve mekânda göreli olduğunu sürekli akılda tutması icap etmektedir. Çünkü Pascal'ın, Pirenelerin bir tarafinda hakikat kabul edilenin diğer tarafinda yanılg1 kabul edildiğini söylerken kastettiği şeyin bütünüyle idrakinde olmak sosyolojik çözümlemenin mihenk taşlarından biridir. En önemlisi, toplumların şaşırtıcı çeşitliliğini ve insanların varoluş biçimlerinin farklılı̆̆ını anlamamızı sağlayan eleştirel sosyolojik perspektif, Giddens'ın (2013, s. 26) belirttiği üzere, diğerlerini yargılamak için kendi toplumunun veya kültürünün bakış açısını ölçü olarak alan etnosantrik anlayışın da panzehridir.

Her bilim dalının kendine has bir dili ve kavramları vardır. Bir disiplinde eleştirel düşünebilmek için o disipline özgü temel kavramların bilinmesi ve yerinde kullanılması çok önemlidir. Fakat bu çalısmada, konuyu analiz etmek ve aydınlatmak için sosyolojik kavramların kullanılması [Madde 9] hususunda, birinci ve ikinci sınıftaki katılımcıların beceri düzeylerinin, "yetersiz" olduğu sonucuna ulaşılmıştır. Bu madde ile ilgili beceri düzeyi, üçüncü ve dördüncü sinıflarda belirgin bir artı̧ göstermiş, yine de "orta" seviyenin üzerine çıkamamıştır. Bu sonuç, sosyolog adaylarının dâhil oldukları bu bilim alanının temel kavramlarını anlama ve kullanma konusunda zorlandıklarını ortaya koymaktadır. Öğrencilerin disiplinin kavramlarına tam manasıyla hâkim olamamaları, toplumsal konuları bu kavramlar aracılı̆̆ıly tartışma becerisinden yoksun olmaları, kısacası dünyayı disiplinin kavramları ve kategorileri bakımından görmekte yetersiz kalmaları sosyolojik perspektif edinemediklerinin bir delilidir. Hâlbuki disipline özgü kavramlarla düşünmeyi öğrenmek, o disiplindeki bir dersin sağlayacağı en değerli kazanımlardan biridir.

Bilişsel bir süreç olan eleştirel düşünme, başkalarının düşüncelerini anlamak, belirli bir soruna veya iddiaya mantıksal bir biçimde yaklaşmak ve kendi düşünsel pozisyonunu oluşturmak için gerekli bir dizi zihinsel beceriyi kapsamaktadır (Baker, 1981, s. 330). Aynı zamanda eleştirel düşünmeye dair öğretim programlarının hedefleri arasında yer alabilecek bu becerilerden bazıları şunlardır (Browne ve Litwin, 1987, s. 384; Ennis, 1993, s. 180): 1) Bir sorunu veya iddiayn açı bir şekilde ifade edebilme, 2) Kavramlar bağlama uygun olarak tanmmlama, 3) Açılayncu sorular sorma, 4) Konuyla ilgili bir pozisyon gelistirme ve onu savunma, 5) Mantıksal cılkarmlarda bulunma, 6) Varsayımlar ve değer çatısmalarm kessfetme, 7) Açı fikirli olma, 8) Kaynaklarm güvenilirliğini sorgulama, 9) Ön yargzl olmama, 10) Sebeplerinin, varsayımlarmm ve kanitlarmmn kabul edilebilirliüi dâbil olmak üzere bir argümann niteliği hakkenda bükeüm verebilme.

Eleştirel düşünmenin yukarıda sözü edilen genel ölçütlerini göz önünde bulundurduğumuzda, bütünsel olarak eleştirel düşünme boyutunda [Madde 10], öğrencilerin beceri düzeylerinin üst sınıflara doğru gidildikçe arttığ1 saptanmıştır. Buna rağmen birinci, ikinci ve üçüncü sınıftakilerin bütünsel eleştirel düşünme becerilerinin "yetersiz", dördüncü sınıftakilerin ise "orta" düzeyden ileriye gidemediği sonucu ortaya çıkmıştır. Bu durumun sebeplerinden biri öğrencilerin eleştirel düşünmeye karşı olumsuz tutumları 
olabilir. Zira eleştirel kelimesi genellikle negatif bir çağrışım yapmaktadır. Eleştirmek olumsuz şeyler söylemek, eleştirel insan hata arayan ve sürekli bir şeylere karşı olan kimse şeklinde algılanmaktadır. Bazı yazarlar (Shepelak vd., 1992; Geertsen, 2003), öğrencilerin eleştirel düşünmeye karşı olumlu tutuma sahip olmalarını muhakeme kabiliyetinden bile daha değerli görmektedir. Hatta Geertsen (2003, s. 4), olumlu tutum olmadıkça en iyi biçimde gerekçelendirilmiş iddiaların bile ancak ve ancak yerleşik dogmayı muhafaza eden bir çit olarak hizmet edeceğini savunmaktadır.

Çalışmada elde edilen sonuçlardan, öğrencilerin, sosyolojik tahayyül [Madde 11] göstergesi olan kişisel sıkıntı-kamusal sorun bağlantısına dair bir farkındalık sergileyemedikleri anlaşılmaktadır. Bu boyuttaki ortalama beceri düzeyleri, birinci ve ikinci sınıftakilerde "çok yetersiz", üçüncü ve dördüncü sınıftakilerde "yetersiz" şeklindedir. Eğitim aşamaları ilerledikçe sosyolojik tahayyül gücünün arttı̆̆ görülmekle birlikte tüm sınıflarda, ölçek maddeleri içindeki en düşük beceri düzeyi bu maddede ortaya çıkmıştır. Bengston ve Hazard (1990) tarafından gerçekleştirilen bir araştırmada varılan sonuçlara göre de, öğrencilerin resmi sosyoloji eğitimi almadan evvelki sosyolojik tahayyül güçleri, eğitim aldıktan sonra kayda değer derecede bir gelişme göstermemiştir. Esasen sosyolojik tahayyül, zihinsel bir vasıf veya bilişsel bir meziyettir; bu yüzden derslerde herhangi bir terim gibi kolayca öğretilemez. Yine de çeşitli pratik ve uygulamalarla ögrencilere sosyolojik tahayyüllerini geliştirme firsatı verilebilir. Özellikle, öğrencilerin sosyolojik kuramın içeriğini kavramalarına ve yazılarında etkili bir şekilde kullanmalarına yardımcı olmak sosyoloji tahayyül edindirme hedefi için kilit bir unsurdur. Mills'e göre (2016, s. 243-244) sosyolojik tahayyül, tarih ile biyografiyi ve bu ikisinin toplumsal yapılar dizisi içerisindeki ilişkisini anlamamızı mümkün kılan bir zihinsel vasıftır. Bu zihinsel vasfin vaat ettiği şey, kişisel gerçekliğimizin geniş çaplı toplumsal gerçeklikle bağlantılı olarak anlaşılmasıdır. Çünkü bireyin yaşamı, biyografisinin içerisinde şekillendiği kurumlara gönderme yapmaksızın gerektiği biçimde anlaşılamaz. Kitle toplumundaki insanlar, farkında olsun ya da olmasınlar, toplumsal sorunlara tercüme edemedikleri kişisel sıkıntılarca kuşatılmıştır. Ne var ki gögüs gerdikleri bu kişisel sıkıntıları çoğu zaman tarihsel değişim ve kurumsal çatışmalarla ilişkilendirerek ele alma kabiliyetinden yoksundurlar. Başka bir deyişle, muhitlere özgü kişisel sıkıntılarla toplumsal yapıya özgü problemlerin karşlıklı etkileşimini kavrayamazlar. Oysa hakiki bir kamu içerisindeki bilgili ve kültürlü insan, tam da bunu gerçekleştirmeye muktedirdir. $\mathrm{O}$, kişisel sıkıntılar olduğunu düşündüğü ve hissettiği şeylerin çoğu kez başka kişilerce de paylaşıldığını ve daha önemlisi bunların tek bir bireyin çabasıyla değil, içerisinde yaşadığı grupların yapısında ve bazen de tüm toplumun yapısında gerçekleştirilecek değişimlerle çözüme kavuşturulabileceğini bilir.

Sosyolojide öğretim hedefleri içinde daima üst sıralarda yer alan eleştirel düşünmenin tezahür edeceği yerler sinıflardır. Bunun için, öğrencilerin sosyolojik tahayyüllerini geliştirmek isteyen öğretim elemanları öncelikle sınıf içindeki geleneksel öğretim uygulamalarından vazgeçmeye hevesli ve yeni yöntemler bakımından yaratıcı olmalıdırlar. Bu bağlamda, öğrencilerde derinlemesine düşünme, tartısmasız kabul edilen inançları eleştirel bir gözle masaya yatırma ve kesinlik iddiasındaki görüşleri çözümleme ve sorgulama yönünde bir alışkanlık yaratmak için geleneksel yöntemlerden ziyade grup çalışmasına teşvik eden, esnek bir öğretim planı uygulamak daha verimli olacaktır. Sözgelimi, geleneksel tek yönlü aktarım yerine öğrenciyi merkeze alan, beyin fırtınası, grup tartışmaları, drama gibi modern öğretim tekniklerinin işe koşulduğu bir öğretim modeli tercih edilebilir. Ek olarak, yazma alışkanlığ1 edinmenin öğrencilerin eleştirel sosyolojik düşünme becerilerini geliştirmede ya da sosyolojik tahayyül güçlerini keşfetmede önemli bir etkiye sahip olduğunu ortaya koyan bazı araştırmalardan (Bidwell, 1995; Massengill, 2011) yola çıkarak, sosyoloji programlarında öğrencilerin yazma kabiliyetlerini geliştirmelerine katkıda bulunacak içeriklere yer vermek düşünülebilir.

Sosyoloji bölümlerindeki öğretim elemanlarının öğrencilere ne düşüneceklerinden ziyade nasıl düşüneceklerini öğretmeye odaklanmaları oldukça önemlidir. Diğer bir ifadeyle, onlardan öğrencilerine belirli fikirleri, inançları, değerleri ve ideolojileri telkin etmek yerine bunları eleştirel ve bilimsel olarak nasıl değerlendireceklerini öğretme konusunda çaba sarf etmeleri beklenmelidir. Öğretim elemanları, öğrencilere alternatif bakış açılarını, fikirleri ve yorumları da sunmalıdırlar. Böylece öğrenci, bu farklı perspektiflerden hangisinin en makul olduğuna ya da kendi değer yargilarıyla uyumlu olduğuna karar verebilecektir. Ayrıca öğretim elemanlarının derslerdeki belirli davranış biçimleri eleştirel düşünme öğretimine yönelik hedefleriyle tutarlı olmalıdır. Öğrencilerinin eleştirel sosyolojik düşünme becerilerinin gelişimine önem veren bir öğretim elemanı öncelikle, her ders boyunca sık sık soru sormalıdır; çünkü eleştirel düşünme, üzerine düşünecek bir sorunun varlığını gerektirir ve öğrenciler genellikle kendilerine firsat tanındığında ya da bu yönde cesaretlendirildiklerinde eleştirel düşünmeye daha meyilli olmaktadırlar. Bu doğrultuda, 
demokratik bir sınıf ortamının yaratılması, eleştirel düşünmenin önündeki engelleri büyük ölçüde kaldıracaktır.

Eleştirel sosyolojik düşünmenin gövereceği sınıflarda öğrencilerin öğrenmenin diplomadan daha önemli olduğunun bilincinde olmaları lazımdır. Soru sormanın onaylanan bir davranış olarak değerlendirildiğini ve hata yapmanın öğrenmenin bir yolu olduğunu bilmeleri de oldukça mühimdir. Altı çizilmesi gereken bir diğer husus ise, eleştirel düşünmenin bir takım zihinsel becerilerin yanında bu becerileri uygulamak için istekli olmayı da içerdiğidir. Dolayısıyla öğrencilerin eleştirel sosyolojik düşünmeye karşı olumlu tutum kazanmalarına yönelik çabaların oldukça yararlı olacağı söylenebilir.

Eleştirel düşünme, kelimelerden veya kavramlardan ibaret bir bilgi kümesi değil, bir süreçtir. Eleştirel düşünme öğretimi, müfredatın sadece yardımcı bir bileşeni gibi düşünülmemelidir. Öğrencilerin eleştirel düşünme becerilerinin geliştirilmesine öncelik veren bir sosyoloji bölümü bu yöndeki çabalarını programındaki tüm derslere entegre etmelidir. Eleştirel düşünmeyi bağlamdan kopuk veya özgül içerik alanlarından ayrı olarak öğretmenin etkisi sınırlı olacaktır. Çünkü eleştirel düşünme belirli bir konu bağlamında gerçekleşmektedir; bu nedenle eleştirel düşünme öğretimi, sırf ona yönelik tamamlayıcı programlardan ziyade disipline dair belirli konuların ya da bağlamların içine yerleştirilmiş bir şekilde öğretilmelidir. Öğretim elemanları bilinçli ve sistematik girişimlerle öğrencileri sürekli olarak eleştirel sosyolojik düşünmeye teşvik etmelidirler. Böylece, öğrenciler için eleştirel sosyolojik düşünme becerileri sadece öğrenim hayatlarında değil, yaşamın her alanında başarllı şekilde uygulayabildikleri bir alışkanlık haline gelecektir.

Sonuç olarak, önemli bir öğrenme çıtısı olan eleştirel sosyolojik düşünme becerisi ile ilgili daha fazla araştırmaya ihtiyaç bulunmaktadır. Gelecekteki çalışmalarda, değişik bölgelerdeki farklı üniversitelerde öğrenim gören öğrencilerin eleştirel sosyolojik düşünme beceri düzeylerinin farklılaşıp farklılaşmadığ veya bu farklılığa etki eden faktörler araştırılabilir. Ayrıca, öğrencilerin eleştirel sosyolojik düşünme beceri düzeylerini nelerin artırabileceğine yönelik deneysel araştırmalar alana kayda değer katkılar sunacaktır.

\section{Etik Beyan}

"Sosyolojide Elesstirel Düsünme: Sosyoloji Öğrencilerinin Elesstirel Sosyolojik Düsünme Beceri Düzeyleri Üzerine Bir Değerlendirme" başlıklı çalışmanın yazım sürecinde bilimsel, etik ve alıntı kurallarına uyulmuş; toplanan veriler üzerinde herhangi bir tahrifat yapılmamış ve bu çalışma herhangi başka bir akademik yayın ortamına değerlendirme için gönderilmemiştir. Makalenin verileri 2018-2019 eğitim-öğretim yllında toplandığından ve makalenin süreci 2020 yllında başladığından etik kurul kararı zorunluluğu taşımamaktadır.

\section{Kaynakça}

Aron, R. (2017). Sosyolojik düşüncenin evreleri (Çev: K. Alemdar). İstanbul: Kırmızı Yayınları.

Baker, P. J. (1981). Learning sociology and assessing critical thinking. Teaching Sociology, 8 (3), 325-363.

Bauman, Z. (2018). Sosyolojik düsünmek.(Çev: A. Yılmaz). İstanbul: Ayrıntı Yayınları.

Bengston, W. F., \& Hazzard, J. W. (1990). The assimilation of sociology into common sense: Some implications for teaching. Teaching Sociology, 18 (1), 39-45.

Berger, P. L. (2018). Sosyolojizye çă̆r: Hümanist birperspektif (Çev: A. E. Koca). İstanbul: İletişim Yayınları.

Bidwell, L. D. M. (1995). Helping students develop a sociological imagination through innovative writing assignments. Teaching Sociology, 23 (4), 401-406.

Brookfield, S. D. (1997). Assessing critical thinking. New Directions for Adult and Continuing Education, 75, 17-29.

Browne, M. N., \& Litwin, L. L. (1987). Critical thinking in the sociology classroom: Facilitating movement from vague objective to explicit achievement. Teaching Sociology, 15 (4), 384-391.

Ennis, R. H. (1989). Critical thinking and subject specificity: Clarification and needed research. Educational Researcher, 18 (3), 4-10.

Ennis, R. H. (1993). Critical thinking assessment. Theory Into Practice, 32 (3), 179-186.

Ethridge, D. E. (2004). Research methodology in applied economics. New York: John Wiley \& Sons, Inc.

Geertsen, H. R. (2003). Rethinking thinking about higher-level thinking. Teaching Sociology, 31 (1), 1-19.

Giddens, A. (2013). Sosyoloji: Kısa fakat elestirel bir giris (Çev: Ü. Y. Battal). Ankara: Siyasal Kitabevi.

Grauerholz, L., \& Bouma-Holtrop, S. (2003). Exploring critical sociological thinking. Teaching Sociology, 31 (4), $485-$ 496.

Gravetter, J. F., \& Forzano, L. B. (2012). Research methods for the behavioral sciences. Belmont, CA: Wadsworth.

Green, C. S., \& Klug, H. G. (1990). Teaching critical thinking and writing through debates: An experimental evaluation. Teaching Sociology, 18 (4), 462-471.

Kunkun, L. (2015). Validity considerations in designing a writing test. Studies in Literature and Language, 10 (5), 19-21.

Leming, J. S. (1998). Some critical thoughts about the teaching of critical thinking. The Social Studies, 89, 61-66.

Lipman, M. (2003). Thinking in education. Cambridge: Cambridge University Press. 
Logan, C. H. (1976). Do sociologists teach students to think more critically? Teaching Sociology, 4 (1), 29-48.

Massengill, R. P. (2011). Sociological writing as higher-level thinking: Assignments that cultivate the sociological imagination. Teaching Sociology, 39 (4), 371-381.

McPeck, J. E. (1990). Teaching critical thinking: Dialoque and dialectic. New York: Routledge.

Mills, C. W. (2016). Sosyolojik tahayyül (Çev: Ö. Küçük). İstanbul: Hil Yayın.

Montgomery, K. (2002). Authentic tasks and rubrics: Go beyond traditional assessments in college teaching. College Teaching, 50, 34-39.

Nosich, M. N. (2016). Eleștirel düşünme ve disiplinler arası eleştirel düşünme rebberi (Çev: B. Aybek). Ankara: Anı Yayınc1lık.

Paul, R. W. (1992). Critical thinking. Santa Rosa, CA: Foundation for Critical Thinking.

Paul, R. W. (2012). Critical thinking: What every person needs to survive in a rapidly changing world. In J. Willsen ve A. J. A. Binker (Edt.). Santa Rosa, CA: Foundation for Critical Thinking.

Ruminski, H. J. ve Hanks, W. E. (1995). Critical thinking lacks definition and uniform evaluation criteria. Journalism and Mass Communication Educator, 50, 4-11.

Shepelak, N. J., Curry-Jackson, A. ve Moore, V. L. (1992). Critical thinking in introductory sociology classes: A program of implementation and evaluation. Teaching Sociology, 20 (1), 18-27.

Turgut, M. F. ve Baykal, Y. (1992). Ölcme teknikleri. Ankara: ÖSYM Yayınları.

Wade, C. ve Tavris, C. (1993). Critical and creative thinking: The case of love and war. New York: HarperCollins.

\section{EXTENDED ABSTRACT}

One of the most important and common teaching goals of Sociology Departments in universities is to develop students' critical thinking skills regarding social facts. Critical thinking specific to sociology discipline includes different skills than critical thinking in other disciplines. Critical sociological thinking refers to the ability to evaluate a problem or argument reasonably and discreetly with the awareness and sensitivity of the social forces that affect it and the social context in which it is shaped.

Critical sociological thinking requires the ability to look beyond points that are widely accepted or formally defined for the purposes of human actions and a certain awareness that social events have different levels of meaning. The aim of ensuring that students have the skills to understand society from different perspectives is at the heart of sociology education. This marks the efforts for gaining students the ability to move from one perspective to another and the mental qualification that Mills (2016) calls "sociological imagination". Because guiding students to think critically means helping them understand personal reality in connection with a wide range of social reality. At a time when higher education institutions tend to produce technicians at an increasing rate, it is very important to raise individuals who benefit from the idea of historical and social structure in their thoughts, who understand and face the structural conditions that reveal problems, and who have a wide sociological imagination.

Sociologists have understood the value of learning critical thinking, and many have developed various teaching strategies to encourage students' development in this area; but so few have empirically tested critical thinking. In other words, although sociologists place critical thinking at the top step of their curriculum goals, empirical research designed to assess such an educational achievement is scarce. This study aimed to measure the critical sociological thinking skills of undergraduate students in sociology related to social issues and to test whether these skills have improved or improved as the education stages progressed within the department's regular curriculum.

In the study carried out according to the descriptive research model convenient sampling method, one of the non-probability based sampling methods was used. The data were obtained from the students enrolled in the Department of Sociology at Adiyaman University in the spring semester of the 2018/2019 academic year. Of the 121 participants in total, 40 are first grade, 34 are second grade, 20 are third grade and 27 are fourth grade. Students were asked to write a composition on a subject designed to determine their critical sociological thinking skill levels and the data of the study were obtained from these compositions. In the analysis of the data, "Critical Sociological Thinking Scale" developed by Grauerholz and Bouma-Holtrop (2003) was used.

The findings of the study evaluating the critical sociological thinking skills in 11 dimensions revealed that the skill levels of the students increased both in each dimension and in general as the education stages progressed within the regular curriculum of the department. However, it is difficult to say that students' critical sociological thinking skills have finally reached the desired level. It is understood that the applied curriculum is not effective enough to provide students with critical thinking skills specific to discipline. 
Places where critical sociological thinking instruction will manifest are primarily classrooms. The lecturers who want to improve students' sociological imaginations should be keen to give up traditional teaching practices in the classroom and be creative in terms of new methods. In this context, it would be more efficient to implement a flexible teaching plan that encourages group work rather than traditional methods to create a habit of thinking deeply, critically discussing beliefs considered undisputed, and analyzing and questioning opinions that claim certainty. It is very important that the lecturers in the departments of sociology focus on teaching students how to think rather than what to think. In other words, they should be expected to strive to teach their students how to critically and scientifically evaluate them, rather than suggesting certain ideas, beliefs, values and ideologies. Teaching staff should also offer students alternative perspectives, ideas and comments. Thus, the student will be able to decide which of these different perspectives is the most reasonable or compatible with their own value judgments. Accordingly, the creation of a democratic classroom environment will largely remove the obstacles to critical thinking.

Critical thinking is a process, not a set of information consisting of words or concepts. Critical thinking teaching should not be thought of as just an auxiliary component of the curriculum. A sociology department that prioritizes the development of students' critical thinking skills should integrate their efforts in this direction into all courses in their program. In our opinion, the effect of teaching critical thinking apart from context-detached or specific content areas will be limited. Because critical thinking takes place in the context of a particular subject; therefore, critical thinking instruction should be taught in a particular context or context of discipline rather than complementary programs for it. Teaching staff should encourage students to critical sociological thinking through conscious and systematic initiatives. Thus, critical sociological thinking skills for students will become a habit that they can successfully apply not only in their learning lives, but in all areas of life.

As a result, more research is needed on critical sociological thinking skills, which is an important learning outcome. In future studies it can be investigated whether the critical sociological thinking skill levels of students studying in different universities in different regions have differentiated or the factors affecting this difference. In addition, experimental research on what can improve students' critical sociological thinking skill levels will make significant contributions to the field. 